\title{
Institutional Legitimacy and Co-Management of a Marine Protected Area: Implementation Lessons from the Case of Xcalak Reefs National Park, Mexico
}

\author{
David M. Hoffman
}

\begin{abstract}
This paper is an exploration of the relationship between a conservation intervention and the quest for local institutional legitimacy and conservation success through co-management. More precisely, this paper will employ the case of Xcalak Reefs National Park (PNAX) to illuminate the interaction between contextual and procedural elements of co-management implementation, how these variables affect the production of legitimacy in the minds of local resource users, and how resultant attitudes can subvert both management devolution and resource conservation. The failure to produce co-management will be related to the mismatch inherent in attempts to map co-management onto a histories and institutions that do not align with the morality and practicalities necessary for its implementation. The case reiterates the necessity for conservation managers and practitioners to have an understanding of local history and context. Lastly, Xcalak demonstrates the dangers for the success of conservation and development programs inherent in management processes that are inconsistent with built expectations. In so doing, this paper highlights critical assumptions made in the real-world application of co-management, as well as inherent conflicts found between local and extra-local moralities that guide conservation work.
\end{abstract}

Key words: co-management, conservation, legitimacy, marine protected areas, Mexico

\section{Introduction}

$\mathrm{T}$ This paper will analyze the case of Xcalak, Quintana Roo, Mexico and the implementation of co-management in its adjacent marine protected area (MPA), Parque Nacional Arrecifes de Xcalak (Xcalak Reefs National Park, PNAX). Fieldwork revealed that many Xcalakeños felt that the government had little or no legitimate authority to govern either the park or their behavior. In addition, the behavior and commentary of conservation authorities indicated

David M. Hoffman is an assistant professor at Mississippi State University in the Department of Anthropology and Middle Eastern Cultures. The research presented here was supported by a J. William FulbrightGarcía Robles fellowship to Mexico, 2003-2004. In addition, preliminary research was supported by the University of Colorado-Department of Anthropology and the Developing Areas Research and Teaching (DART) Pre-Dissertation grants. I am indebted to Dr. Maria Cruz-Torres and Dr. Benjamin Blount for their significant and helpful insights on earlier versions of the paper. I am also deeply indebted to Dr. J. Terrence McCabe for his guidance in the development of the dissertation that produced this article. Lastly, I would like to thank the anonymous reviewers from Human Organization for their constructively critical assessments. This paper is much stronger due to their helpful commentary. that they too had little confidence in the Xcalakeños' ability to manage. Further, depredation continued unabated within the park's boundaries.

Considering the community's "poster-child" status in various publications as an example of community-driven, co-managed conservation (see Bezaury Creel 1997; Bezaury Creel et al. 1998; Chung 1999; Lopez et al. 1997), the oppositional stance of the community towards the park's management, observance of continued resistance to park and fishery rules, and community sentiment that the park was for anyone but the Xcalakeños were curious. How had an ostensibly participatory and inclusive process of park formation and management produced such negative attitudes and actions? This is contrary to the laudatory writings on the devolution of authority via co-management that espouse its ability to produce resource conservation and legitimate authority (see Agardy 1997; Cambell and Vainio-Mattila 2003; Jameson, Tupper, and Ridley 2002; Lane 2001; Lepp and Holland 2006; Little 1994; National Research Council 2001; National Marine Protected Areas Center 2004; Ostrom 1990, 1994; Ostrom et al. 2002; Stern et al. 2002; Wells and Brandon 1992; Wells and McShane 2004; Wells and White 1995; West and Brechin 1991; Western and Wright 1994a, 1994b; Wilshusen et al. 2002). 
This paper will present an analysis of the Xcalak context and Xcalakeño perceptions of PNAX's formation to illustrate both the problematic implementation of co-management and its impacts. As well, the interaction of local institutions with the moralities and priorities of the larger context of Mexican conservation and development will be considered. Most importantly, the case will show the local attitudinal and behavioral repercussions produced by unrealized expectations and promises of co-management that created a legitimacy crisis for PNAX and affected locals' acceptance and acquiescence to the park's rules. In part, the crisis was due to the problematic mapping of co-management onto histories and institutions with which it aligns poorly.

The PNAX story reinforces existing scholarship regarding the difficulties in creating effective co-management of resources both within and outside of protected areas (PAs). First is the significant hurdle co-management faces in engaging government entities and their representatives. Second, the Xcalak experience demonstrates that local institutions can be inappropriate foundations upon which to build conservation initiatives. Third, the perceived or real capture of co-management processes by either local elites or outsiders is a significant problem. Finally, the pace and manner of implementation has impacts on local perceptions of the PA authority's legitimacy. Ultimately, these demonstrate that critical attention must be paid to the implementation process.

In addition to reflecting the co-management literature, the PNAX case also sheds light on critical questions within conservation social science. The highlighted problems reverberate with recent analyses of whom and what conservation areas are for, and how the interaction between global and local needs creates overlapping and often contradictory mandates (cf. Child 2004; Murphree 2004). Thus, the problems in implementing co-management in Xcalak expose conservation effort's deeper legitimacy problems expressed in the following questions: Does co-managed conservation produce a local commons and support local livelihoods? Or, are PA interventions only conserving a national or global biodiversity commons?

\section{Legitimacy and Co-Management}

The scope of this paper does not permit an exhaustive review of the various interpretations of legitimacy in social science. The concept is seen in a variety of different ways and has a multitude of meanings. Dugan (2004) states that legitimacy is about "rights" in the sense of power to make decisions or represent others, and it is also about being "right" in the moral, normative sense. In Weberian sociological theory, focused mainly on interactions between individuals or between individuals and the state, legitimacy is defined as "the property of a situation or behavior that is defined by a set of social norms as correct or appropriate" (Wilshusen et al. 2003; Weber 1978). Jentoft (2000) adds that "legitimate" management must be justified according to moral principles and values. Thus, a management system's social justice is as important as its legal foundation.
Notions of legitimacy and power relations can and need to be related to existing social institutions; rules, norms, and laws. Wilshusen et al. (2003) defines institutionally based power as the enactment of everyday social practices linked to rules typically understood in legal, economic, religious, familial, or other terms. As well, he states that institutions and institutional order are based on symbolic systems, which inform social practices. Steinmo, Thelen, and Longstreth (1992) show that institutions are built upon the past, in that social actors do not entirely replace institutions with new ones, but, rather, they are built upon past rules, norms, laws, and procedures. Finally, Wilshusen et al. (2003: 51) reminds us that institutions are multiple and conflicting, overlapping and contradictory, and are often the source of conflicts. Thus, institutions can be viewed as a set of symbolic palimpsests structuring individual and group agency. Jentoft (2000:142) urges us to remember that, "legitimacy is neither stable nor a fixed thing, rather it is something that changes over time."

Theories of legitimacy generally indicate that participatory processes, such as co-management, will grant more legitimacy to the management of natural resources (Jentoft 2000; Wilshusen et al. 2003). "A group seen as representative will have legitimacy that a group that is seen as excluding interests will not have, and any agreements will be less likely to be attacked" (Barnett in Dugan 2004). In particular, co-management has been touted as an effective manner in which to manage common pool resources (CPRs), such as fisheries, which suffer from the problems of excludability and subtractability, and are susceptible to the "tragedy of the commons" (Pomeroy and Berkes 1997). Even before Hardin's (1968) treatise on the commons, governance of such resources typically relied upon either top-down governmental management or privatization to prevent the tragedy. However, the continued failures of both to produce legitimate authority, stem the abuse of CPRs, or end conflicts between resource users and government authorities led to a search for more effective, legitimate management arrangements.

Co-Management arose as a solution focused on the "sharing of power and responsibility between governments and communities" and representing "a middle course between State management and pure communal property" (da Silva 2004:419-420). This middle course is characterized by participatory and decentralized decision-making that is aimed at ensuring the involvement of resource users in the management decisions regarding regulations, implementation, and enforcement (Jentoft, McCay, and Wilson 1998:423).

Co-Management of CPRs was theorized as having two critical repercussions. First, inclusive decision-making would enable local users' knowledge to "produce more enlightened, effective, and equitable remedies and solutions to management challenges" (Jentoft, McCay, and Wilson 1998:423). Second, participation would "enhance the legitimacy of the regulatory regime, and hence, compliance" (Jentoft, McCay, and, Wilson 1998:423). Put another way, co-management is about empowering oft-excluded local resources users and stakeholders by shifting power and management responsibility (Jentoft 
2004). Pinkerton (1994:320-321) states, the inclusion of local knowledge and perspectives can "make the difference between systems having local legitimacy or not, having local relevance or not...." Thus, in theory, co-management should produce effective and legitimate resource governance.

In the 1990s, theorists and conservation professionals began calling for co-management in conservation (Lane 2001). Traditional PA management largely ignored local perspectives and economic development in pursuit of conservation. It was evident that exclusionary, top-down, "fortress conservation" methods of conservation were failing to conserve biodiversity and producing conflicts with local people (Borgerhoff-Mulder and Capolillo 2005; Brockington 2001; Igoe 2004; Neumann 1998). These issues led conservationists to search for ways to integrate local concerns into PA management and gain their cooperation (Borgerhoff-Mulder and Capolillo 2005; Lane 2001).

Conservation co-management should be understood as "formal arrangements facilitating the participation of local people in planning and management" (Lane 2001:663). As with CPRs, the theorized benefits of co-management for PAs are multiple. First, it would ensure the collaboration between PA managers and local people, bringing local needs to the table, and minimize conservation's social impacts (Lane 2001). Second, by recognizing the link between the social context and conservation, it would avoid past exclusionary practices that compromised a PAs ability to protect biodiversity (Lane 2001). Lastly, co-management would reduce the need for managers to enforce PA rules and could lead to voluntary or self-regulation on the part of local people.

Co-Management is assumed to create more efficient and effective conservation by changing local perceptions of and behavior in PAs. As Lane (2001:665) puts it, "In these circumstances, the protected area manager can rely on voluntary compliance and cooperation with management prescriptions, rather than seeking to enforce or defend the protected area boundary, seeking to keep an unsympathetic local public at bay."

In this way, co-management of protected areas was proposed to empower local stakeholders as a way of not only reducing the social impact of conservation, but also improving the capacity of managers to meet conversation and other (development) objectives (Lane 2001:663, my emphasis). Clearly, a significant aspect of conservation co-management is producing legitimate authority to facilitate locals' cooperative behavior.

The positive rhetoric found within much of the early literature on PA co-management is, perhaps, overstated. Observers cautioned against the overwhelming optimism (Lane 2001). West (1991:xxii) states, "For the most part it is too early to tell. There are early signs of promise in specific cases...based on prescriptive hopes, plans, and dreams; others on impressionistic, qualitative judgments after early steps in initial implementation." Lane (2001) astutely cautions that realizing these theorized benefits and effectiveness of co-managed conservation is dependent on how it is implemented.
The utilization of co-management to build legitimate management and conservation often fails to take into account the contextual variables that work against it. Jentoft (2000) suggests that co-management itself may be the source of legitimacy problems in that the government may not trust resource users to follow rules, and resource users may not be willing to grant legitimacy to decisions made by managers, scientists, and other outsiders. The PNAX case fits neatly into this conversation on the relationships between implementation, legitimacy, collaboration, and conservation.

\section{Research Methods}

The findings presented here are based on 11 months of fieldwork conducted during 2003-2004. The initial stages of fieldwork were focused on gathering data on the various livelihoods of the community and the behavior of Xcalakeños in relation to the conservation of marine resources within PNAX and neighboring Banco Chinchorro Biosphere Reserve. These data were collected via participant observation of fishing, tourism, and other livelihood activities. In addition, informal interviews were conducted.

The second, and more pertinent, stage of fieldwork elicited the relationships between the co-management of PNAX, individual and community sentiments regarding park management, and behaviors noted during participant observation. Data were gathered through two formal research instruments. First, semi-structured interviews were conducted with 32 heads of household (30 male, 2 female) regarding resource use, livelihoods, participation in management, and attitudes toward conservation. Purposive sampling was used to target a broad and representative spectrum of livelihood strategies including: fishermen, tourism workers, hoteliers, business owners, and government employees. Second a questionnaire was randomly administered to 31 people not contacted during the semi-structured interviews ( 20 male, 11 female) eliciting attitudes and recollections regarding resources and park management. ${ }^{1}$ The questionnaire contained scalar questions to test attitudes, as well as free-listing questions aimed at determining Xcalakeños' basic knowledge of institutions and issues they felt were important. In sum, 64 individuals were contacted via these research instruments, which represent 23 percent of the population of the 276 residents (INEGI 2000).

\section{The Xcalak Case}

Xcalak is located at the very southern tip of the state of Quintana Roo's coast about eight km from the border between Mexico and Belize. Land access comes from either a dirt beach road (built in the 1980s) or a newly built paved road (built in the mid-1990s) that skirts the lagoons and mangroves that lie directly to the west. Prior to the existence of these roads, the only way to reach the community was via boat. Xcalak's physical isolation has impacted its development, as well as the community's nature and culture. 
Figure 1. Map of Conservation Areas of Quintana Roo, Xcalak Reefs at bottom. Source: Lopez, Merediz, and Rubinoff (2003)

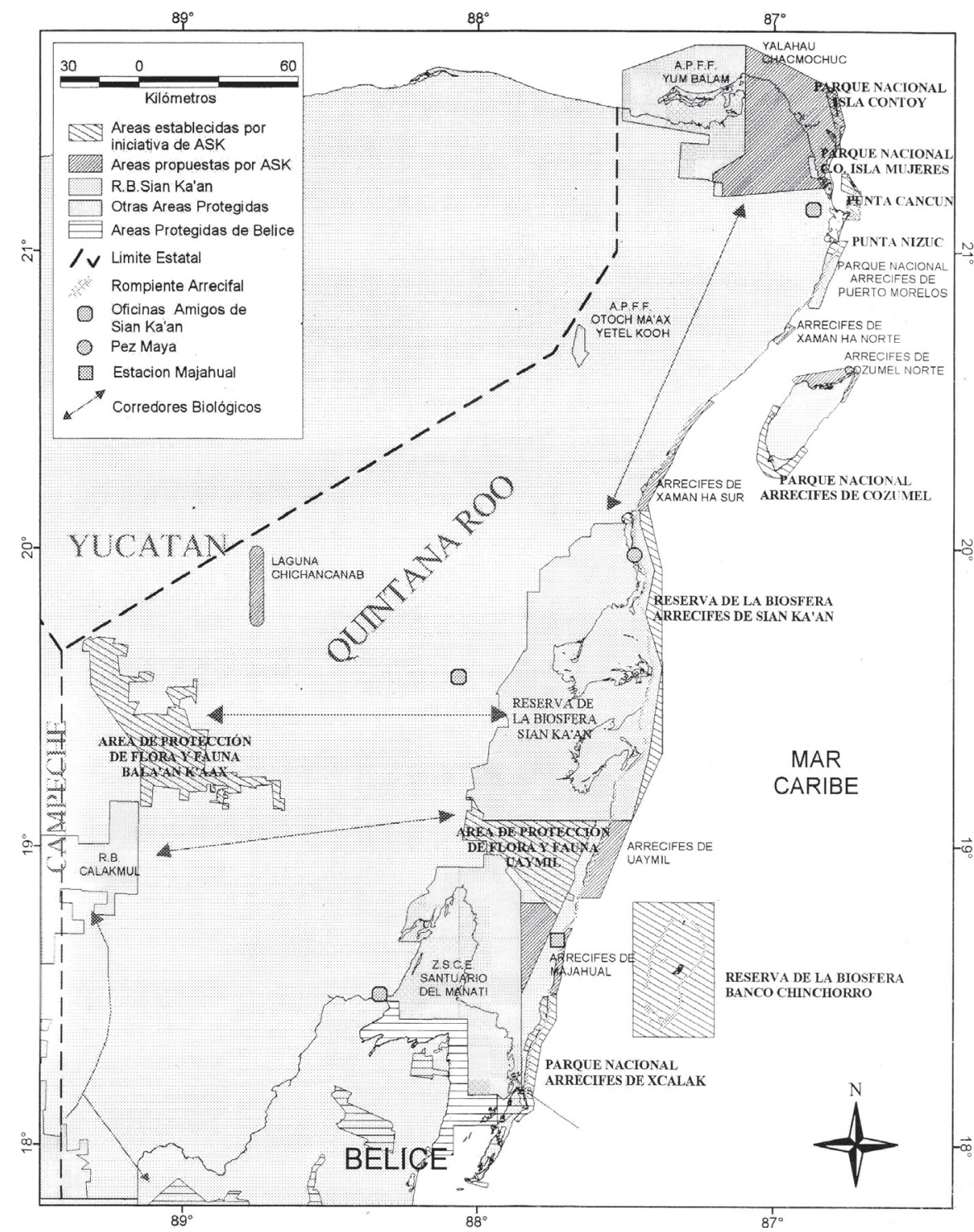

The population of Xcalak has been slowly increasing over the past half century with marked growth in the last $10-15$ years. This growth is due to the repopulation of native Xcalakeños combined with the slow migration of people from Veracruz, Campeche, and Yucatan (Daltabuit et al. 2003). Foreigners from Belize, Spain, United States, and Honduras have also recently come to the community (Daltabuit et al. 2003). Household surveys show that almost 70 percent of Xcalakís population was born in the state of Quintana Roo, while 25 percent were born in other states of Mexico or in other countries (Daltabuit et al. 2003). Xcalakís population can be described as Mestizo, with under nine percent of the population considered to be indigenous Maya (INEGI 2000).
Poor soils, limited land, and scarce fresh water significantly restrict livelihood options. Thus, the ocean and coral reefs (part of the worldís second largest barrier reef system, the Mesoamerican Reef) offer Xcalak both subsistence and economic opportunity. Since the foundation of its fishing cooperative in 1959, the community of Xcalak has been defined by small-scale commercial fishing. Fishing became central to the economic life of the community only after Hurricane Janet in 1955 devastated the Xcalak area (Lopez et al. 1997). Prior to Janet, Xcalak depended upon the production of copra (dried coconut meat). In the 1990s, tourism and its services began to employ more Xcalakeños as the area was linked to Quintana Rooís tourism economy. Currently, most Xcalak households 
participate in a pastiche of economic activities that include both fishing and tourism. Extended families live in close proximity, if not on the same property, and often aggregate several salaries from various jobs to make ends meet.

Fishing remains a central economic component of the community and is a critical aspect of its self-identity. Daltabuit et al. (2003) found that over 50 percent of household members claimed fishing as their self-defined profession. In comparison, tourism only accounted for 11 percent, empleado (employee) was at 11 percent, and construction, commerce, and agriculture accounted for 5 percent each.

\section{Xcalak and its Common Pool Resources: An Impending Tragedy}

In many ways, the fisheries of Quintana Roo and Xcalak, especially lucrative species such as Panilirius argus (spiny lobster) and Strombus gigas (queen conch), seem to be prime examples of Hardin's (1968) “Tragedy of the Commons.” This is surprising considering that, between Janet's destruction of the copra industry and the initiation of tourism in 1980s, Xcalak was utterly dependent upon fishing for its livelihood (Basurto 1997). It seems logical that these coastal people would have developed institutions to regulate the commons, thereby controlling and preventing the overexploitation of fisheries resources. Instead, a number of factors produced a tenuous open-access situation in pre-PNAX Xcalak. This open-access situation, despite the fact that the Xcalak cooperative holds the only legal concession to the local reef, is a clear reflection of well-documented problems with Mexican fisheries policy.

Since the 1970s, Mexico's fisheries policies have largely been focused on creating growth in fisheries landings (Hernandez and Kempton 2003). Prior to the 1970s, the federal government did not seriously consider fisheries as a tool for economic development (Aguilar, Reid, and Thorpe 2000). After the declaration of its exclusive economic zone (EEZ) in 1976, Mexico began to realize the economic potential of its fisheries (Simonian 1995). The 1970s witnessed the growth of the fishing industry, emphasis on luxury export fisheries, and production regardless of environmental costs. Government policies and subsidies for both industrialized fishing and artisanal cooperatives increased fisheries landings until 1981 but also drove overexploitation (Hernandez and Kempton 2003).

Historically, the Mexican state pursued fisheries policies that were intended to support both small-scale producers and export-led development for aggregate economic growth (Young 2001). In accordance, Young (2001) points out that concessions to valuable fisheries were given exclusively to cooperatives, which then channeled their product through state-run processing and export companies. However, co-op members are not the only fishermen that can gain access to fish resources. Free fishermen are also allowed to exploit maritime resources, and they are ostensibly required to obtain a permit from fishing authorities. Free fishermen were not legally given access to export species, but cooperatives are largely unable to stop them from gaining access (Young 2001).

To increase productivity and promote sustainable fisheries, neoliberal reforms since the 1980s have meant that the state has deemphasized its support for cooperatives, opened fisheries to private investment, and reduced cooperatives' exclusive access (Young 2001). Unfortunately, both cooperativist policies and neoliberal reforms of the fishery sector encouraged the abuse of ocean resources. Young (2001:288) says, "Past and present fishery policies have transformed social relations of production in small-scale fishing communities by encouraging collective abuse of the marine commons and fomenting conflicts over access among different users."

Abuse of the ocean commons in Mexico is also a product of extremely weak enforcement by the Mexican state. Large territories, the mobile nature of fish resources, allocation of limited financial resources, and corruption inhibit the enforcement of fishery regulations (Young 2001). Also, the dual categories of cooperative and free fishermen worsened the situation by encouraging dual, overlapping access rights to marine resources (McGoodwin 1987; Young 2001). These overlapping access rights and low governmental enforcement create an open access situation in many nearshore fisheries, making cooperatives both unwilling and unable to effectively police their own concessions (McGuire and Langworthy 1991; Vasquez-Leon 1994; Young 2001).

\section{The Xcalak Fishery}

Fishery development for commercially valuable export species in Quintana Roo has generally followed the trajectory described above. Exploitation of lobster and conch in southern Quintana Roo only began seriously during the late 1960s, shortly after Xcalak's cooperative was formed (Basurto 1995; Miller 1982). Immediately, they were subjected to heavy exploitation by both cooperative and free-fishermen, driven by increasing connections to markets (especially the tourism market growing in Cancun) and by state policies. Further, there was little enforcement of the legal mechanisms intended to protect the resources and limit access to cooperatives (Miller 1982, 1989; CONAPESCA 2000).

To this day, cooperative fishermen frustrated by open access to resources supposedly reserved for their exploitation and enticed by the lucrative black market engage in unabated exploitation of lobster and conch regardless of the regulations limiting size and seasons that have been imposed since the 1980s (Hoffman 2006; Miller 1982). Rather than fomenting institutions to control access to the fishery, poaching among Xcalak's fishermen was reinforcing its open-access nature and replicates the "tragedy of incursion" as described by McCay and Acheson (1987).

One crucial factor driving the overexploitation of both Xcalak's and Quintana Roo's fisheries is the fact that the state's coastal population consists of relatively recent migrants with little experience managing fisheries. Again, the Xcalak community is largely comprised of immigrants that 
Figure 2. Lobster Catches in Mexico, Quintana Roo, Yucatan. Source: FAO (2003)

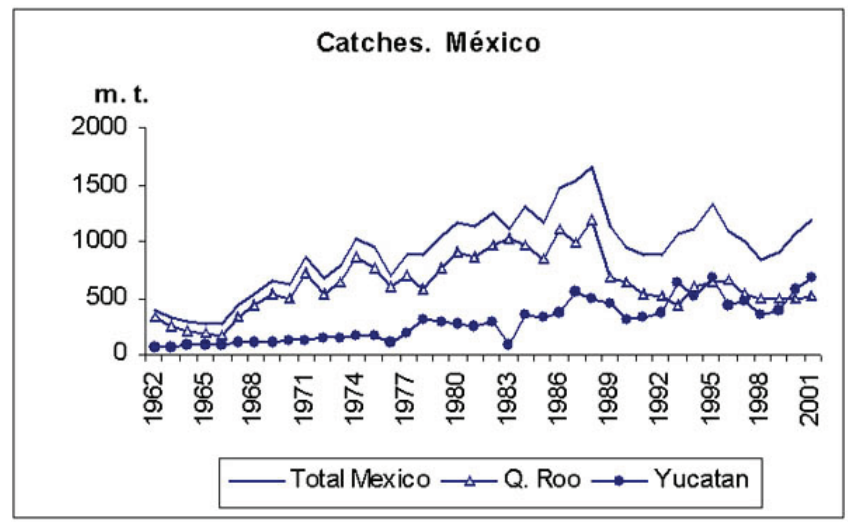

arrived after Hurricane Janet (Daltabuit et al. 2003; Lopez et al. 1997). This means that the community and cooperative are only entering their third generation of experience. Thus, Xcalak's fishing history parallels that described by Young (2001) in Baja California. Young (2001:291) observes, "Given the relatively recent formation of fishing communities in these areas, no formalized set of community-based resource use practices evolved for collective management of local fishing activities." This aptly describes Xcalak's fishery prior to the park initiative (see Figures 2 and 3).

\section{The Rise of Tourism}

An additional threat to Xcalak's resources is the state and federal governments' tourism development plans for the southern coast of Quintana Roo. By the early 1990s, tourism presented new livelihood opportunities to Xcalak. However, the social and ecological threats tourism brings were well known to both Xcalakeños and the environmental NGO, Amigos de Sian Ka' an (ASK). The threat of tourism impacts similar to those seen in Cancun provides a critical backdrop to PNAX's development.

In the early 1970s, the Mexican government via a parastatal organization called the National Fund for the Foment of Tourism (FONATUR) began developing Cancun as one of four Integrated Tourism Centers (Simon 1997). Prior to this time, Cancun was a small fishing camp that had few permanent residents. The Cancun project, with money from the Inter-American Development Bank (IADB) and the Mexican government, was intended to create an exclusive resort area using the area's natural beauty as a prime attraction (Torres-Maldonado 2000). However, after its initial years of exclusivity, development shifted to mass-scale tourism (Torres-Maldonado 1997). This tourism was based on the construction of many massive all-inclusive resorts, as well as a whole series of large-scale food and entertainment
Figure 3. Lobster Catches in the Yucatan Peninsula; States of Quintana Roo and Yucatán. Source: FAO (2003)

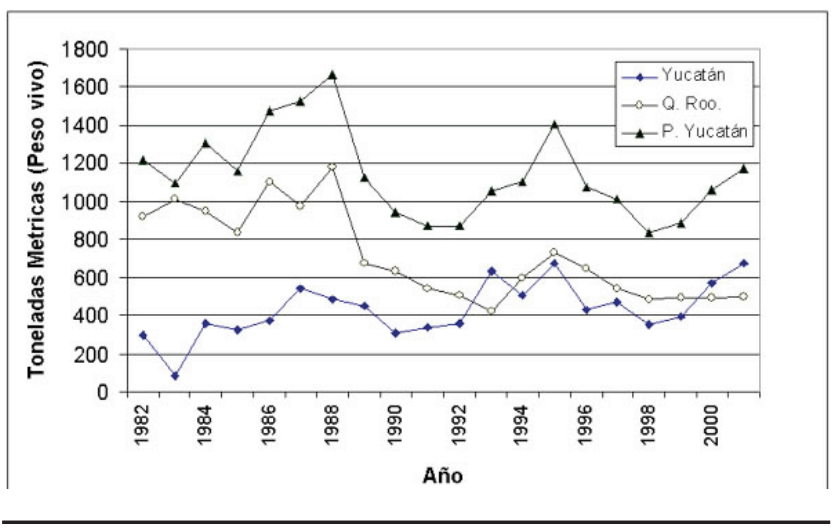

establishments. By the end of the 1990s, the city of Cancun had grown to over 300,000 residents and became the largest city in the state (Bezaury Creel et al. 1998; Robadue and Rubinoff 2003).

Simply put, Quintana Roo's development has been driven by tourism. By the beginning of the $21^{\text {st }}$ century, 85 percent of the state's economic activity came from tourism, with most of it concentrated in the Cancun-Tulum coastal corridor known as the "Riviera Maya" (Robadue and Rubinoff 2003). By the late 1990s, the corridor attracted over two million visitors a year and over 20,000 hotel rooms were built (Robadue and Rubinoff 2003). The Cancun-Tulum corridor's tourism economy generates approximately one-third of Mexico's tourism income (Bezaury Creel et al. 1998).

The Cancun-Tulum corridor's incredible growth has had many negative effects. For example, the Nichupte lagoon, which lies between the city center and the hotel zone of Cancun, has been severely polluted (Robadue and Rubinoff 2003; Torres-Maldonado 1997). Population growth due to migration is also a serious side effect of tourism development. The inability of state and local governments to organize proper sanitation, sewage treatment, and garbage disposal has had serious impacts on coastal ecosystems. The deteriorating conditions of the reefs and wildlife in the north can be largely attributed to the inadequate management of population and industrial growth. Despite the fact that the Riviera Maya has a state level development plan (POET) to control impacts, the overwhelming force of migrants coming to build and staff the resorts of the corridor has surpassed state and local government capacity. Some even say that the state government has intentionally ignored provisions of the POET so as to not discourage tourism's continued economic growth (Murray 2003).

Massive migration and rapid urbanization also brought many of the social ills related to poverty and urban living. Most of the jobs created are menial labor in construction or 
service work. Various researchers have detailed the decay of traditional Maya cultural values, the poor conditions of the service communities, and the increases in statistics of violence and drug and alcohol abuse (see Bray 2001; Brown 1999; Daltabuit and Pi-Sunyer 1990; Juárez 2002; Pi-Sunyer and Thomas 1997; Pi-Sunyer and Daltbuit 1999; Re-Cruz 1997). In general, tourism in the north has meant that ownership of the coast has been transferred to foreigners, internal elites, and multinational corporations. Locals and migrants are generally relegated to the poorly planned service communities.

In the 1990s, the federal and state governments turned their gaze to the undeveloped southern coast of Quintana Roo, including Xcalak, as a new tourism frontier. The area was dubbed "Costa Maya," and the idea was to convert the Xcalak peninsula into an international ecotourism Mecca (Simon 1997). The state development plan for 1993-1999 focused on the infrastructural and legal development of the Costa Maya to stimulate both economic growth and protect ecosystems via sustainable tourism (GQR 2000; Lopez, Merediz, and Rubinoff 2003; Robadue and Rubinoff 2003).

At the same time, the ecological consequences of tourism growth in the North spawned an environmental consciousness in the area's middle class, manifested in the rise of the environmental NGO the ASK (Simon 1997). Originally focused on the Sian Ka' an Biosphere Reserve, in the 1990s ASK expanded its projects throughout the state, focusing on coasts threatened by tourism development. Thus, the PNAX initiative was born out of past experience and new threats from tourism, as well as new ideas regarding sustainable development via conservation.

\section{The Early Park Process: A New Hope for Xcalak}

According to informants, the park idea started soon after representatives from the ASK began coming to Xcalak in the early 1990s. ASK was involved in assessing the state of the region in an attempt to define critical conservation needs. In the process, they brought their message of alternative development through ecotourism. Xcalakeños knew the governments' plans to develop tourism in the Costa Maya and were wary of its social and environmental impacts due to their familiarity with what transpired in the north of the state. At this time, Xcalak's tourism was nascent, and only the most dedicated divers and fly-fishers visited the isolated community. Yet, some fishermen began to get involved in tourism and realized that the work and pay were agreeable. Thus, they were beginning to see tourism's potential, especially in light of the general decline in fisheries production. This combination sowed the seeds of PNAX.

The park initiative was largely credited to the efforts of one individual, a former delegado (roughly equivalent to mayor). In 1995, he drafted letters to the governor of Quintana Roo and the federal resource and protected area authority (SEMARNAP), asking for their help to create a national MPA (Lopez et al. 1997; Murray 2003; Robadue and Rubinoff 2003). This proposal simply suggested protection for La Poza (an attractive dive spot with a unique and well-preserved coral structure and abundant fish populations) and solicited advice to help the Xcalakeños protect their jobs and resources.

These letters, which some say were a product of the influence of ASK, truly initiated the park process. Soon thereafter, the mayor received a response from the Instituto Nacional de Ecologia (National Institute of Ecology, INE) regarding the petition. The letter said it was necessary to produce a thorough characterization of the biological and social settings, along with a preliminary plan for park regulations and borders required for a National Park declaration (Robadue and Rubinoff 2003). This assessment required the expertise of technocrats that neither the federal government nor Xcalak could provide. It was into this vacuum that ASK, funded through USAID and the University of Rhode Island's Coastal Resource Center (URI-CRC), began to officially work with the community of Xcalak to produce the required documentation.

ASK, URI-CRC, and other private and governmental interests began the process of characterizing the resources of the area, identifying critical conservation issues, and creating a park proposal (Robadue and Rubinoff 2003). ASK also sponsored community workshops designed to raise environmental consciousness and improve the Xcalakeños' capacity to take advantage of the changes brought about by the shift to conservation and tourism. In 1996, ASK facilitated the creation of a Comité Comunitario para la Proteccion y Manejo de los Recursos Costeros de Xcalak (hereafter the Comité) to be the contact point and voice for the community regarding park issues.

Soon the efforts of ASK began to pay off. The series of meetings they conducted with the community brought about a fully elaborated park proposal. By 1997, the collaboration put the community (via the Comité) and ASK's vision into a formal document, A Community Strategy for the Management of the Xcalak Zone (Lopez et al. 1997). It included the results of the aforementioned social and biological assessments of the area. It also contained a proposed park with a mixed zoning plan that maintained areas for sustainable use (fishing by cooperative members and free fishermen), as well as zones for tourism and no-take zones for fishery reproduction. It is important to note that in this document the proposed park was considerably larger than just La Poza.

The Community Strategy document outlines the situation of the community in 1997, the need for capacity-building, and a vision for the management of PNAX (Lopez et al. 1997). The Community Strategy included a very detailed characterization and proposal for PNAX that was submitted to SEMARNAP authorities in March 1997 (Lopez, Merediz, and Rubinoff 2003). A critical aspect of these documents was an emphasis on the community's future role in the park's decision-making. The idea was planted that co-management of PNAX would not end upon its declaration, and that community input would remain integral. 


\section{Figure 4. Timeline of Events in History of PNAX}

1994/1995: Declaration of the Costa Maya by the State of Quintana Roo

1995: $\quad$ Letters sent by Delegado to Governor, SEMARNAT / INE for assistance in creating a park in Xcalak

1995: $\quad$ Collaboration between ASK / USAID / URI-CRC / WWF-Mexico begins for Integrated Coastal Management in Quintana Roo

1995: $\quad$ SEMARNAT / INE response to Xcalak's delegado for more formal proposal with technical assessment

1996: $\quad$ ASK / URI-CRC begin workshops to develop community park proposal and strategy

1996: $\quad$ Formation of the Comité Comunitario

1997: $\quad$ Community Strategy document published including proposed park zoning and regulations. Submitted to SEMARNAT / INE for consideration.

1997-1999: INE response indicates need to integrate state and local authorities, come to agreement. Various meetings between community, state, and national authorities.

2000: $\quad$ Declaration of Parque Nacional Arrecifes de Xcalak in the Diario Oficial of Mexican government.

2000-2002: Elaboration of the official park management plan, Programa de Manejo

2002: $\quad$ Founding of Consejo Asesor (Assessment Council) as organization in charge of working towards consensus of various sectors for the Programa de Manejo (Management Plan)

2003-2004: Management plan awaits official approval by SEMARNAT officials in Mexico City

Much of the community work done by ASK and URICRC was to convince skeptics that the park would benefit, not threaten, the community (Murray 2003). This included convincing Xcalak's fishermen that the park proposal would be a mechanism to protect fishing resources by limiting outside incursion. As is clear in the Community Strategy, the Park would not only conserve Xcalak's reefs and mangroves, but it would facilitate the community management of its resources, retention of tourism's economic benefits, and preserve fishing traditions central to community identity. Thus, one can interpret that the underlying intention was to create institutions to replace the existing open-access regime. The proposed MPA would stem the "tragedy of incursion," facilitate sustainable fisheries, and foster local tourism livelihoods.

In 2000, president Ernesto Zedillo declared PNAX. This declaration marked one of the few times that a community had successfully petitioned the federal government for the creation of a park (Lopez, Merediz, and Rubinoff 2003). In addition, the success of this "bottom-up" process heralded an important victory for community-based conservation initiatives, specifically for MPAs in Mexico. The unfulfilled expectations for PNAX and its management that were evident in the feelings and behaviors recorded in 2003-2004 soon subsumed these auspicious beginnings. To demonstrate this shift, we must first detail Xcalakeño recollections of early management.

\section{Early Participation and Expectations of Co-Management}

During interviews many Xcalakeños commented that the early collaboration between ASK and the Comité went quite well, and there was significant community participation. They felt that the community actually came together-for the most part - in support of the submitted park proposal.
One informant, a forty-year-old fly fishing guide, described this early work saying, "We received a lot of help from the Amigos de Sian Ka'an to continue this project. They were always here aiding us." 2 Another interviewee said, "There was a meeting here with the whole town. They made a management plan between everyone from fisherman to the rest of the town's inhabitants."

These quotes illuminate the positive recollection of these early decisions. Much of this positive perception lay in the assumption, fueled by the ASK's rhetoric, that there would be a continued role of Xcalak in the park's management. This is summarized by the same fly fishing guide's statement, "many people wanted the community to always participate, to be in the management." When asked if the people in town believed that they would have power in this project, a 38-year-old guide responded, "The [people have the] power to manage this project, that the people of the community would manage it."

The projection of future participation in management is not only evident in the perceptions of Xcalakeño informants, but can also be gleaned from the publications of ASK and URI-CRC (see Lopez et al. 1997). For example, Chung (1999:12) cites that Comité's main objective was "to have a forum where the community can design and propose management actions with the purpose of promoting the conservation of natural resources and the development of the region." Interviews with ASK employees reiterated that the intention was for the integral involvement of Xcalakeños in park decisions. Thus, the expectation of community involvement in the next stages of park implementation was fostered by the rhetoric of outside actors and by the early experiences of many involved.

Yet as Murray (2003) discusses, it is important to note that even the early process of the park proposal was contentious. 
Developing the park proposal was often described as an exciting time in which there was significant participation of the community, although consensus was not immediate. These initial meetings were described to me by a 37 -year-old fishermen/cooperative director as:

Very long, very contentious and really the social organizations that one encountered in this moment were not in agreement [about the park]. Really, it had to organize a little, by making a Comite that which the Amigos de Sian Ka'an, an NGO, had the first opportunity to teach [us] the first steps in regard to conservation of the environment.

A 38-year-old tourism guide said that the community was divided at the initiation of the park project because "it was difficult to be able to get the people to understand the benefits that could come." For him, this reticence came from their lack of experience with a project of this nature and skepticism of the outsiders' motives. Murray (2003) emphasizes that many of the community's fishermen were concerned that a park would eliminate their ability to continue their livelihood.

It is also important to not imbue the Comite as representative of all interests in Xcalak. From 2000-2003, the Comite was comprised of the director of the tourism and fishing cooperatives (the same man for both), the mayor, and a representative of the business community. Murray (2003:377) cautions those reviewing the collaboration between the "community" and ASK saying, "The Comité has never represented the views of the entire community. Or perhaps it would be better to say that the community never spoke with just one voice. The process...involved only certain members of the community: members and ex-members of the Comité...."

Interviews reinforced the exclusion that some people felt regarding the park or the meetings that brought it about. One non-native Xcalakeño said, "It was never done publicly... what they tried to do at the beginning was a species of monopoly." He went on to explain that there was only a public discourse after the plan was completed and brought to the community by officials. A Xcalakeño carpenter complained that a few individuals, invited by the authorities, captured the process. He said, "The important people gained friendship-I know the people, but never [did they say to me] 'Hey, come here, you're invited'... They never solicited my opinion." A fly fishing guide said he participated at first, but that later he "wasn't informed of what was happening."

In addition to representation, impatience and frustration with the slow nature of the park process affected opinions of the initiative. After having sent the proposal to the offices of SEMARNAP in March of 1997, the community and ASK faced considerable political roadblocks (see Hoffman 2006; Murray 2003). The long delay between the production of the Community Strategy (1997) and the federal declaration of the park (2000) meant that community interest and momentum had been largely lost (Murray 2003). Murray (2003) noted in 2001 that much of the community support of the initiative had eroded, and that fears of overzealous restrictions were resurfacing.
This growing frustration was often reflected in interviews. For some, community management began to wane when the park itself was declared in 2000. A 41-year-old guide noted that even the official decree of the park disrespected the community-ASK proposal. He said, "The petition of the town was not respected...I have read in one part of the decree that this park will be managed by SEMARNAP and the Secretariat of the Navy. At no time does it say that it will take into account the town; that the town will be in the management." Thus, almost immediately after the park arrived within the domain of the federal officials, participatory management seemed threatened.

These sentiments continued to grow within the community of Xcalak, especially during the elaboration of the Programa de Manejo (Management Plan). While the park decree was opaque regarding the community's role in PNAX management, the management plan process reinforced their secondary role and was a critical crucible in which disenchantment with the park was forged. Community perspectives on this process will be thoroughly discussed below; however, the domination by federal authorities was not produced in a vacuum.

\section{Mexican Conservation and National Parks}

There are three critical factors regarding the formation and management of national parks and protected areas in Mexico that are pertinent to the Xcalak case. First, there is little institutional history of participatory mechanisms in Mexican conservation (see De La Maza 1999; Murray 2003; Simonian 1995). Further, the federal bureaucracies in charge of governing parks are young institutions. De La Maza (1999) and Murray (2003) point out that the current organizational structure of Mexican conservation has only existed for a little over 15 years and is built upon a history of state-dominated processes. In fact, the federal law known as Ley General del Equilibrio Ecológico y la Protección al Ambiente (LGEEPA) exclusively charges SEMARNAT (a restructured SEMARNAP), and no one else, with the elaboration of management plans (Gates 1998).

Second, Mexico's protected area program is grossly underfunded. Murray (2003) states that financing for National Parks is woefully inadequate, forcing parks to find alternative sources of funding such as: debt-for-nature swaps, multilateral aid, donations from visitors, and donations from NGOs and private foundations. It was only in 2001 that parks were authorized to collect daily use fees from visitors (Murray 2003). The National Protected Areas Commission (CONANP) predicts that such fees can only generate 25 percent of their budget, and few parks will become self-sufficient (CONANP 2001).

Third, Mexican PAs are woefully understaffed due to the aforementioned lack of financing. CONANP (2001) cites that there were only 260 people assigned to 60 natural protected areas, leaving more than half without field staff. Understaffing means that park personnel can do little more than take note of 
existing problems. The problems of budgets and lack of staff for vigilance of the park were particularly problematic for PNAX in 2003-2004. It is critical to keep these three factors in mind during the following discussion of attitudes and the elaboration of PNAX's official management plan.

\section{Elaboration of the Management Plan and Its Effects on Co-Management}

Despite the clear signals of waning enthusiasm captured by Murray $(2003,2005)$, more significant issues developed during the elaboration of the management plan from 2000 to 2003. Interviewees indicated that it was during the design of the management plan that the co-management of PNAX effectively ended. In fact, the rupture between the idealized notions of co-management that initially encouraged them to pursue the park and the reality of interacting with the federal conservation authorities significantly influenced community perceptions observed during fieldwork in 2003-2004.

In general, there was a qualitative shift in the decisionmaking process for the official park management plan. Interviewees maintained that the federal officials and ASK began to focus less upon meetings among the general population, and instead came to rely upon the Comité and later an organism called the Consejo Asesor (Assessment Council) as a proxy for the community. In March 2002, the Consejo Asesor was developed as a participatory, multi-stakeholder body charged with developing PNAX's official management plan. The Consejo was established as a permanent point of articulation between the SEMARNAT and the "community" writ large (not just Xcalak). ${ }^{3}$ The Consejo was a participatory mechanism for various stakeholders, and the meetings were technically open to anyone (COFEMER 2003). Four meetings of the Consejo were held in 2002-2003 to reach consensus on the official PNAX management plan.

The Consejo is comprised of 33 representatives of various governmental, NGO, business, and community members (COFEMER 2003). Community representation on the Consejo $(18 \%)$ consisted of the president of the cooperatives (fishing and tourism), the mayor, one community member, and three tourism operators. The rest of the Consejo was made up of State, Federal, and Municipal government officials $(55 \%)$, academics $(15 \%)$, and NGO representatives $(12 \%)$. Clearly this represents a shift in the locus of decisions away from Xcalak and towards a community defined on a larger, regional scale.

\section{The Management Plan: Perceptions and Impacts}

The perception that the management plan process moved (even physically) away from participation was summarized by a 25 -year-old Xcalakeño fisherman. He explained:

Because when the management plan started, only like two or three times was there a meeting here with the entire community. They talked about more meetings that were going to be here... They had them at the University of Quintana Roo, the offices of SEMARNAP [sic], and other unfixed locations. The town didn't help at all in the management plan. Only the delegado and the director of the two cooperatives went.

It was clear that this young man felt that the community had been pushed aside in favor of the Consejo. This was a sentiment that was expressed often by saying that the entire process had become "puro directivo" (only directors).

The use of the Consejo as the community voice seemed inexplicable to many interviewees. However, some individuals knew that the change was due to federal law regarding the formation of a management plan. One particularly astute fishermen and tour guide understood this mandate and described the shift in this manner:

It was [originally] the community and Amigos de Sian $\mathrm{Ka}$ 'an with the government. But it turned out that Xcalak Reefs was not done at the state level. We had it be Federal so that it would be more respected. So, the laws say to us in an article...that it puts us to one side. This is the annoyance we have with the Amigos de Sian Ka'an. The Amigos say that they are not at fault because only the government can regulate the maritime. In other words, that it is all federal.

He is pointing out that the federal government is the ultimate authority because all coastal waters are the property of the State and because they chose the national park route.

A 38-year-old hotelier lucidly explained the ways in which participation had shifted in the elaboration of the management plan. She said,

Really the people didn't make that management plan. The agencies came with that management plan to show it... The government said, 'Here we have the management plan.' They never sat with us and said, 'Lets make that management plan.' They brought it already completed. When they brought the management plan, the people said nothing. But this is normal-what do the people know about what the management plan says? They only use technical words... This is what happened, but they never sat and said to you, 'Listen, lets sit down everyone and what do you think? What are we going to do? How is it? Is this OK?' Never.

That federal agencies prepared the document and then brought it to the community was corroborated by the 39-year-old park guard saying, "But, they did the management plan, the government agencies, the community did not participate. We did not participate."

At the same time, many felt it was unjust for federal officials to work only with the former directors of the Comité (that were now on part of the Consejo) rather than the general population. In defense of the federal agencies, the changes to the management plan were relatively small and it makes sense that officials relied on the directors to expedite the process and minimize costs while maintaining consultation. However, 
for those that participated in the original plan for the park, the perceived capture of the process by the influential and politically well positioned was disheartening.

One particularly influential person was the cooperative president. Because he served on both the Comité and the Consejo, it appeared as though the fisheries cooperative became the "go to" organization for community consent with the management plan. As an existing organizational structure and a powerful entity within the community, it was particularly important that the fishing cooperative give its consent to the management plan. Further, co-op members held the only official rights to exploit the marine resources that would be affected by the park. The cooperative president was clearly on board with the conservation project and his presidency gave him some sway (i.e., loans, gasoline, and permits) over the opinions of the cooperative members.

In the end, the park's management plan was submitted to the fishing co-op for consent. However, the decision to work mostly with the cooperative and its leadership left many non-members feeling disenfranchised. As the hotelier expressed it:

For the management plan, supposedly all of that was the group that was there - community. Not only cooperative. It's community, between everyone: townspeople, cooperative members, and tourism operators. This is how it should have been. But after the fact, I don't know what happened over there, that everything was "whatever the president of the cooperative says." So, like they said, "Well, what's happening if this is everyone's, not only one person?" And with all of this, I became discouraged because it is the community's, not only one person!

Interviewees also expressed that community participation in the management plan process diminished because local meetings decreased. A 31-year-old tourism guide/fisherman summarized this sentiment saying, "In the management plan they have not had many meetings on the part of the government, but I believe that they are doing it on behalf of town, no? One time they came to have a meeting for the management plan, but that was it. Now the government they have not returned." To complicate matters further, some interviewees admitted that they did not go to the few meetings that were called to finish and approve the plan. Some cited that the meetings were held during the day when they had to work, others were out fishing in Banco Chinchorro, and others mentioned that they were not informed of the meetings. Yet, several interviewees also said that the people of Xcalak simply were not interested in attending meetings. As one Xcalakeño divemaster put it, “The truth also, many people don't go to the meetings to give their opinion."

As stated earlier, the meetings of the Consejo regarding the management plan were technically open to everyone (COFEMER 2003). The authorities covered the various aspects of the plan, community members were provided the opportunity to voice their concerns about specifics within the document before the Consejo, and the fishing cooperative ratified it. Yet most interviewees could not speak to the specifics of the plan, citing that they never saw the actual document. In fact, it was never given out en masse to the community, but a draft was presented to the fishing cooperative. Once approved, the plan sat in Mexico City awaiting official publication for the year and a half that passed between the final meetings and the time of this research. This bred unfamiliarity, unease, and mistrust. As one man put it, "It has been two years since one has seen the management plan. We don't know how it is."

In sum, it is clear from the above discussion that informant's perceptions of the park process, despite some positive recollections, was that it moved from a collaborative, participatory, and seemingly "bottom-up" process with the promise of co-management to a consultative top-down management system in which the locus of control rests firmly with outsiders, federal authorities, and a select few community representatives. In fairness to SEMARNAT, bringing the plan to the community via the Consejo for its approval was at least consultative and represents an important initial step away from unilateral, top-down decision-making in Mexican parks.

\section{Existing Participation in Park Management and Its Effects}

Previous discussion shows that the elaboration of the management plan was less participatory than desired. Further, the final document is unclear regarding current and future community involvement (see CONANP 2004). Community participation will likely take a back seat to more consultative processes with the Consejo as the point of articulation. However, it is obligatory to provide a note of caution regarding the interpretation of the management plan as a fixed and static document. The document will see revision processes and federal officials emphasized that the document provides a de jure outline of the park. Park managers reassured me that the de facto enforcement and utilization of the various aspects of the plan can and will be adjusted.

Despite reassurances regarding the future, the current participation of Xcalakeños was clearly indicated in the questionnaire results. When asked to evaluate "how much they participate in the decisions made of the protected area" (scale of 1 to 5 , where $1=$ no participation and $5=$ very active participation), the average response was 1.77 . This signals that the average Xcalakeño was participating very little or not at all. In fact, 45 percent $(n=14)$ answered that they do not participate at all in the decision-making. Only one person answered "active" and not one person answered "very active." These data show that a considerable portion of the community is not involved in park management.

Levels of participation not only effected perceptions of the park and its management, but it also had significant impacts on resource use. Continual excessive pressures on valuable fisheries resources within the park were observed and well-known. The lack of governmental or community enforcement meant that the park was neither controlling outsiders' access nor conserving the resources for local fishermen. 
Thus, one of the primary goals of establishing PNAX was not occurring due to the lack of funds and Xcalakeños' lack of will to enforce the rules themselves.

The lack of vigilance played a part in the production of the following discourse, commonly overheard in Xcalak and offered by a cooperative fisherman:

\begin{abstract}
At times we are taking care [of resources] and people from outside come. They...enter the Xcalak National Park, and it is an area where fishing is not allowed. Then they enter, fish, and take the product away. Then, sometimes we are threatened and we take the issue to the authorities via the directors [of the co-op]. The directors go and talk with SEMARNAT, they get together and are going to send inspectors, but they are only words because they don't arrive, they don't come.
\end{abstract}

This statement shows that Xcalakeños blame resource depredation on outsiders; however, they themselves can be implicated in poaching. It is unfair to characterize all Xcalakeño fishermen this way, but people and authorities knew that locals entered no-take zones with impunity. The park guard summarized the perpetrator's thinking by saying, "If I don't enter, well, another will. See, so, I'll do it as well. If there was the law paired with vigilance, neither I nor anyone else would enter."

It is clear that the situation in Xcalak in 2003-2004 represented a continuance of locals' long history of inability to prevent incursion and open access in their concession. As a result, faith was not only lost in park participation, but also in the park as a mechanism to control "their" resources. Perhaps most indicative of mistrust and legitimacy issues were the responses to the questionnaire question, "Who receives most of the benefits from the protected area?" Among the free list, only one response mentioned "the community" and one other indicated "society." However, 15 percent of responses were that they "did not know," 33 percent of responses suggested "outside investors" or "gringos," and a full 30 percent said some form of "Ellos mismos (Them themselves)" (referring to the park's managers and/or ASK).

\section{Discussion: Legitimacy, Unfulfilled Promises, and Overlapping Visions}

The Xcalak case reflects existing scholarship regarding the difficulties of implementing co-management while providing insight into the exact ways in which the implementation process affects local attitudes and behavior. It demonstrates that, despite calls for the devolution of power to communities in development and conservation via processes such as co-management, many such projects fall back on traditional forms of authority. The reasons for this tendency are multiple and interrelated.

Xcalak's co-management experience reiterates that a significant hurdle faced by co-management is the government and individual actors within these bureaucracies. As Pomeroy and Berkes (1997:467) cite, "Unless governments and decision-makers who implement government policies can be convinced of the desire and the ability of users to manage themselves, not much progress can be made in co-management." One can see government reluctance and doubt in the efficacy of co-management in the fact that there existed few opportunities outside of the Comite and Consejo for Xcalakeños to engage with management decisions. The case provides convincing evidence in support of Pomeroy and Berkes' (1997:469) assertion that for co-management to work the "government must not only foster conditions for fisher participation but sustain it."

The apparent disinterest of the government to sustain such processes was, in part, due to a mistrust of the Xcalakenos ability to conserve the resources, which in turn was exacerbated by the known incursions and disrespect of conservation regulations on the part of community members. On the other side of the equation, the community demonstrated a classic reluctance to either relinquish authority or take on too much responsibility (Chuenpagdee and Jentoft 2007). Not only was there a legitimacy problem for the government in the eyes of the community, but also vice versa. As Pomeroy and Berkes (1997) suggest, in co-management it takes "Two to Tango," and the mutual mistrust regarding ability and authority was at the root of PNAX's problems.

Another considerable and problematic hurdle in Xcalak was related to the perceived and/or real capture of co-management processes by local elites or outsiders. It is important to remember that outsiders (ASK), who had little history with the community, started the PNAX initiative. Scholars of co-management have shown that trust between sponsor and affected parties, especially those not integrated into the community, and particularly NGOs, can cause problems (Chuenpagdee and Jentoft 2007). As noted, Xcalakeños were skeptical of ASK, its motives, and those who associated with them.

In terms of local elites, there was clearly a perceived capture of the process by "los meros" (the bosses). In particular, there existed a mistrust of the president of the cooperatives, as well as his motives related to the park. This illuminates another known implementation problem in co-management, that of relying upon inappropriate local leadership. As Pomeroy, Katon, and Harkes (2001:200) put it, "While a community may already have leaders, they may not be the correct or appropriate leaders for co-management."

Reliance on the cooperative and its leadership in Xcalak also reiterates the need to conduct groundwork to understand whether the existing institutional context is conducive to comanagement. Scholarship suggests that existing institutions of resource management can be inappropriate foundations upon which to build conservation initiatives, especially those of fishermen (Pomeroy and Berkes 1997). Co-Management rests upon the notion that it will build collaboration through already existing local institutions. Yet the short and one-dimensional history of Xcalak's main resource institution (the co-op) reiterates that this cannot be assumed for all small communities. Thus, the PNAX experience is a clear example of Pomeroy and Berkes' (1997:468) warning that if such institutions do 
not exist in a context, then "any co-management initiative will necessarily start with institution-building." However, it is clear that not enough attention was paid to these issues for PNAX, reiterating Chuenpagdee and Jentoft's (2007) point that the failure to adequately investigate contexts can lead to poorly implemented or failed interventions.

Not only was the process of the PNAX intervention problematic, but the pace in which steps were made had a significant impact on perceptions of the project's legitimacy. Research demonstrates that slow implementation can be interpreted as "failure to deliver," causing disillusion among communities and governors (Chuenpagdee and Jentoft 2007:467). Discontent with PNAX was bred by the fact that the official management plan was taking so long to implement, that it had remained out of sight in Mexico City, and that negligible community consultation occurred in the meantime.

Finally, the sensed lack of contact and communication captured in Xcalak also replicates existing analyses of the relationship between co-management implementation and legitimate authority. The formation of legitimacy for both the local community and the resource managers need to be based on consistent and meaningful forms of communication. It is useful here to look at the insights of Svein Jentoft (2000:144) into the relationship between legitimacy and resource management:

Legitimacy does not only rest on normative foundation such as respect for the authority of the state...Rather, it also requires that agreement has been established through a truly communicative process that, as Habermas would define it, is rational, free of domination of any kind, and allows equal access for all participants.

The communication that existed between government authorities, NGOs, and the community of Xcalak cannot be characterized as such.

\section{Conclusion}

In 2004, Xcalak showed that problematic implementation of co-management in conservation can actually work to inhibit the empowerment and agency that is supposed to bring local people into the fold, create economic opportunity, reduce the need for rule enforcement, and reduce conflicts between locals and management. The PNAX experience shows that unrealized expectations and promises of co-management can lead to negative attitudinal and behavioral repercussions. Simply put, the park's rules and regulations were frequently disregarded by local users, and there was no movement on the part of the community towards self-regulation.

Interviews and questionnaires conducted in Xcalak show that the sort of co-management theorized and proposed in the original collaborations between ASK and the community had largely fallen by the wayside. What started as a series of promises regarding local control and benefit was transformed into an imposition of outside governmental authority legitimated by processes of consultation channeled through certain individuals. PNAX deviated from the tenets of co-management by taking a consultative form, which had significant impacts on the thoughts and behavior of Xcalakeños. While perfect community representation is nearly impossible, it is clear that the notion of a co-management based in the community itself was not implemented despite the original intentions and rhetoric crucial to the community's initial "buy-in."

The attitudes and behaviors observed in Xcalak were not driven simply by the deviation away from community participation. The socioeconomic, cultural and historical context also played a significant role. Evidence discussed here shows that it was a miscalculation to map co-management over a context in which both community and state institutions were not aligned for co-production of legitimacy through collaboration. Rather, we see continued historical relations of domination and submission. PNAX also demonstrates that historical roles of government and citizens are difficult to eliminate. Instead, the implementation of participatory approaches to conservation has usually meant small adjustments in structure that create little space for community-level agency. PNAX presents an attempt at implementing change that does not question or challenge the deep schemas (cognitive cues, scripts, and or/procedures) that frame interpretation and action (DiMaggio 1997; Wilshusen et al. 2003).

In conclusion, the Xcalak story shows the way in which varied perspectives on the reason, rationale, and constituency of conservation affect the process and outcomes. PNAX brings to the forefront the inherent conflicts between the desires and expectations of communities, NGOs, and the federal government. Local actors want to conserve resources to maintain their utilization and control. The other actors' interest lies in serving the national and global constituency's need for the conservation of the global biodiversity "commons." The PNAX case shows how these contradictions play out in management, as well as the effects upon community opinion and use of resources. Ultimately, PNAX and Xcalak demonstrate that, regardless of which commons we are trying to promote (local or global), much more attention needs to be paid to contextual variables, the process of project implementation, and their influence on local opinion and behavior. If not, the aims of conservation and community development will remain elusive at best.

\section{Notes}

\footnotetext{
${ }^{1}$ These questionnaires were administered randomly to unsuspecting individuals. In order to achieve this, the author waited in various locations within the community in an attempt to come across a broad spectrum of the community's residents. Locations that were chosen included two separate locally owned stores/snack shops (twice), a bar (once), the beach (three times), the side of the main road (once), and a hotel (once). While this method was not a perfect randomizing device, it did produce a broader cross-section of the community than the author's targeted interviews. In addition, the author waited at different times at each place in the hopes of catching people that might be occupied at different times due to their personal employment, school, or family situations. Some interviews were conducted in the informant's home after having encountered them randomly during the day, but deferring
} 
the questionnaire until a better time. The questionnaire is available upon request.

${ }^{2}$ In the interest of space, quotes have been provided in their English translation only. The original Spanish quotes are available upon request.

${ }^{3}$ Rule 5 defines the Consejo in this manner: Consejo: The Consejo Asesor of Xcalak Reefs National Park, constituted via the Act dated March 23, 2002, as a consultative and aid organ, integrated with representatives of the public, social, and private sectors, with interference [interest] in the natural protected area.

\section{References}

Agardy, Tundi S.

1997 Marine Protected Areas and Ocean Conservation. Austin, Tex.: R. G. Landes Co.

Aguilar, Alonso, Chris Reid, and Andy Thorpe

2000 The Political Economy of Marine Fisheries Development in Peru, Chile, and Mexico. Journal of Latin American Studies 32:503-547.

Basurto, Martha

1995 Descripcion de las Pesquerias del Sur de Quintana Roo (Punta Putilcub-Xcalak y Banco Chinchorro). Cancun: Amigos de Sian Ka'an.

1997 La Pesca Comercial. Boletin de Amigos de Sian Ka'an, 3843.

Bezaury Creel, Juan

1997 Integrated Coastal Management of Xcalak: A Unique Opportunity. Amigos de Sian Ka'an Bulletin: Special Edition Xcalak 17.

Bezaury Creel, Juan, Carlos López Sántos, Jennifer McCann, Concepción Molina Islas, Jorge Carranza, Pamela Rubinoff, Townsend Goddard, Don Robadue, and Lynne Hale

1998 Participatory Coastal and Marine Management in Quintana Roo, Mexico. Paper presented at the International Tropical Marine Ecosystems Management Symposium, Townsville, Australia, November 23-26.

Borgerhoff-Mulder, Monique, and Peter Coppolillo

2005 Conservation: Linking Ecology, Economics, and Culture. Princeton, N.J.: Princeton University Press.

Bray, David B.

2001 The Mayans of Central Quintana Roo. In Endangered Peoples of Latin America: Struggles to Survive and Thrive. Susan C. Stonich, ed. Pp. 3-18. Westport, Conn.: The Greenwood Press.

Brockington, Dan

2001 Fortress Conservation: The Preservation of the Mkomazi Game Reserve, Tanzania. London: Earthscan.

Brown, Denise F.

1999 Mayas and Tourists in the Maya World. Human Organization 58:295-304.

Cambell, Lisa M., and Arja Vainio-Mattila

2003 Participatory Development and Community-Based Conservation: Opportunities Missed for Lessons Learned? Human Ecology 31(3):417-437.
Child, Brian

2004 Parks in Transition: Biodiversity, Rural Development, and the Bottom Line. In Parks in Transition: Biodiversity, Rural Development, and the Bottom Line. Brian Child, ed. Pp. 233-256. London: Earthscan.

Chuenpagdee, Ratana, and Svein Jentoft

2007 Step Zero for Fisheries Co-Management: What Precedes Implementation. Marine Policy 31:657-668.

Chung, Beth R.

1999 ACommunity Strategy for Coastal Zone Management of Xcalak, Mexico. In Community-Based Land Use Planning in Conservation Areas: Lessons from Local Participatory Processes that Seek to Balance Economic Uses with Ecosystem Protection. America Verde Training Manual No. 3. Vienna, Va.: Development Partners P.C.

Comisión Federal de Mejora Regulatoria (COFEMER)

2003 Minutas de la Reunion para El Establecimiento del Consejo Asesor del Parque Nacional Arrecifes de Xcalak. Mexico, D.F.: Comisión Federal de Mejora Regulatoria.

Comisión Nacional de Acuacultura y Pesca (CONAPESCA)

2000 Caracol: Golfo De Mexico y Caribe. Lunes 28 de agosto de 2000: 51-52. Mexico D.F.: Comisión Nacional de Acuacultura y Pesca

Comisión Nacional de Areas Naturales Protegidas (CONANP) 2001 Programa de Trabajo 2001-2006. Mexico, D.F.: Comision Nacional de Áreas Naturales Protegidas.

2004 Programa de Manejo Parque Nacional, Arrecifes de Xcalak. Mexico, D.F.: Comision Nacional de Areas Naturales Protegidas.

Daltabuit, Magali, and Oriol Pi-Sunyer

1990 Tourism Development in Quintana Roo. Cultural Survival Quarterly 14(1):9-13.

Daltabuit, Magali, Luz Maria Vasquez, Hector Cisneros, and Gregorio

A. Ruiz

2003 Desarrollo del Turismo Costero en la Ecoregion del Sistema Arrecifal Mesoamericano. Mexico, D.F.: Centro Regional de Investigaciones Multidisciplinarias-Universidad Nacional Autónoma de México.

da Silva, Patricio Pinto

2004 From Common Property to Co-Management: Lessons from Brazil's First Maritime Extractive Reserve. Marine Policy 28:419428.

De La Maza, Roberto

1999 Una Historia de Las Areas Naturales Protegidas en Mexico. Gaceta Ecologica 51:15-34.

DiMaggio, Paul

1997 Culture and Cognition. Annual Review of Sociology 23:263287.

Dugan, Maire A.

2004 Legitimacy. URL:<http://www.beyondintractability.org/ essay/legitimacy $>$ (Accessed November 30, 2006)

Food and Agriculture Organization (FAO)

2003 Report of the Second Workshop on the Management of Caribbean and Spiny Lobster Fisheries in the Wecafe Area. Rome: Food and Agriculture Organization. 
Gates, Marilyn

1998 Eco-Imperialism? Environmental Policy versus Everyday Practice in Mexico. In The Third Wave of Modernization in Latin America: Cultural Perspectives on Neoliberalism. Lynne Phillips, ed. Pp 155-174. Wilmington, Del.: Jaguar Books.

Government of Quintana Roo (GQR)

2000 Programa de Ordenamiento Ecologico Territorial de La Region Costa Maya. Chetumal Quintana Roo, Mexico: Government of Quintana Roo.

Hardin, Garret

1968 The Tragedy of the Commons. Science 162:1243-1248.

Hernandez, Alvaro, and Willett Kempton

2003 Changes in Fisheries Management in Mexico: Effects of Increasing Scientific Input and Public Participation. Ocean and Coastal Management 46:507-526.

Hoffman, David M.

2006 The Subversion of Co-Management of a Marine Protected Area: The Case of Xcalak Reefs National Park, Mexico. Ph.D. dissertation, Department of Anthropology, University of Colorado.

Igoe, Jim

2004 Conservation and Globalization: A Study of National Parks and Indigenous Communities from East Africa to South Dakota. Denver: University of Colorado.

Instituto Nacional de Estadistica, Geografia E Informatica (INEGI) 2000 Migración. URL: $<$ http://www.inegi.gob.mx> (Accessed March 1, 2002).

Jameson, Stephen C., Mark H. Tupper, and Jonathon M. Ridley

2002 The Three Screen Doors: Can Marine "Protected" Areas Be Effective? Marine Pollution Bulletin 44:1177-1183.

Jentoft, Svein

2000 Legitimacy and Disappointment in Fisheries Management. Marine Policy 24:141-148.

2004 Fisheries Co-Management as Empowerment. Marine Policy 29:1-7.

Jentoft, Svein, Bonnie J. McCay, and Douglas C. Wilson

1998 Social Theory and Fisheries Co-Management. Marine Policy 22(4-5):423-436.

Juárez, Ana M.

2002 Ecological Degradation, Global Tourism, and Inequality: Maya Interpretations of the Changing Environment in Quintana Roo, Mexico. Human Organization 61:113-124.

Lane, Marcus B.

2001 Affirming New Directions in Planning Theory: CoManagement of Protected Areas. Society and Natural Resources 14:657-671

Lepp, Andrew, and Stephen Holland

2006 A Comparison of Attitudes Toward State Led Conservation and Community-Based Conservation in the Village of Bigodi, Uganda. Society and Natural Resources 19:609-623.

Little, Peter D.

1994 The Link Between Local Participation and Improved Conservation: A Review of the Issues. In Natural Connections: Perspectives in Community-Based Conservation. David Western and R. Michael Wright, eds. Pp. 1-14. Washington, D.C.: Island Press.
Lopez, Carlos, Jennifer McCann, Concepcion Molina Islas, and Pam Rubinoff

1997 Estrategia Communitaria. Cancun: Amigos de Sian Ka'an.

Lopez, Carlos, Gonzalo Merediz, and Pam Rubinoff

2003 El Manejo Costero Integrado Como un Proyecto Piloto en la Costa Maya: la Realizacion de un Proyecto. Xcalak: Una Experiencia en el manejo de Recursos Costeros. Cancun: Amigos de Sian Ka'an.

McCay, Bonnie J., and James Acheson, eds.

1987 The Question of the Commons: The Culture and Ecology of Communal Resources. Tucson: The University of Arizona Press.

McGoodwin, James R.

1987 Mexico's Conflictual Inshore Pacific Fisheries: Problem Analysis and Policy Recommendations. Human Organization 46:221-232.

McGuire, Thomas R., and Mark Langworthy

1991 Behavioral and Organizational Modifications of Enforcement/ Avoidance Theories: The Fisheries Case. Presented at the second annual conference of the International Association for the Study of Common Property, Winnipeg, Manitoba, Canada, September 26-29.

Miller, David L.

1982 Mexico's Caribbean Fishery: Recent Change and Current Issues. Geography. Milwaukee: University of Wisconsin.

1989 The Evolution of Mexico's Caribbean Spiny Lobster Fishery. In Common Property Resources and Community-Based Sustainable Development. Fikret Berkes, ed. Pp. 185-198. London: Belhaven Press.

Murray, Grant D.

2003 Contextual Influences on Protected Area Form and Function in Quintana Roo, Mexico. Ph.D. dissertation, Department of Natural Resources and Environment, University of Michigan.

2005 Multifaceted Measures of Success in Two Mexican Marine Protected Areas. Society and Natural Resources 18:889-905.

Murphree, Marshall W.

2004 Who and What Are Parks for in Transitional Societies. In Parks in Transition: Biodiversity, Rural Development, and the Bottom Line. Brian Child, ed. Pp. 217-232. London: Earthscan.

National Marine Protected Areas Center

2004 Stakeholder Participation: A Synthesis of Current Literature. Washington D.C.: National Marine Protected Areas Center.

National Research Council

2001 Marine Protected Areas: Tools for Sustaining Ocean Ecosystems. Washington D.C.: National Academy Press.

Neumann, Roderick

1998 Imposing Wilderness: Struggles over Livelihood and Nature Preservation in Africa. Berkeley: University of California Press.

Ostrom, Elinor

1990 Governing the Commons: The Evolution of Institutions for Collective Action. Cambridge: Cambridge University Press.

1994 Neither Market nor State: Governance of Common-Pool Resources in the Twenty-First Century. Washington D.C.: International Food Policy Research Institute. 
Ostrom, Elinor, Thomas Dietz, Nives Dolsak, Paul C. Stern, Susan Stonich, and Elke U. Weber, eds.

2002 The Drama of the Commons. Washington D.C.: National Academy Press.

Pinkerton, Evelyn

1994 Summary and Conclusions. In Folk Management in the World's Fisheries: Lessons for Modern Fisheries Management. Christopher L. Dyer and James R. McGoodwin, eds. Pp. 317-337. Boulder: University Press of Colorado.

Pi-Sunyer, Oriol, and Magali Daltabuit

1999 Tourism and Maya Society in Quintana Roo, Mexico. Occasional Paper, No. 17, Latin American Studies Consortium of New England.

Pi-Sunyer, Oriol, and R. Brooke Thomas

1997 Tourism, Environmentalism, and Cultural Survival in Quintana Roo. In Life and Death Matters: Human Rights and the Environment at the End of the Millenium. Barbara R. Johnston, ed. Pp. 43-60. Walnut Creek, Calif.: AltaMira Press.

Pomeroy, Robert S., and Fikret Berkes

1997 Two to Tango: The Role of Government in Fisheries Comanagement. Marine Policy 21(5):465-480.

Pomeroy, Robert S., Brenda M. Katon, and Igvild Harkes

2001 Conditions Affecting the Success of Fisheries Co-Management: Lessons from Asia. Marine Policy 25(3):197-208.

Re-Cruz, Alicia

1997 The Thousand and One Faces of Cancun. Urban Anthropology 25(3):283-310.

Robadue, Jr., Donald, and Pam Rubinoff

2003 Capacity Building and Strategic Innovation: Conserving Critical Coastal Ecosystems in Mexico 1996-2003. Coastal Management Report, 2244. Narragansett: University of Rhode Island Coastal Resources Center

Simon, Joel

1997 Endangered Mexico: An Environment on the Edge. San Francisco: Sierra Club Books.

Simonian, Lane

1995 Defending the Land of the Jaguar: A History of Conservation in Mexico. Austin: University of Texas Press.

Steinmo, Sven, Kathleen Thelen, and Frank Longstreth, eds.

1992 Structuring Politics: Historical Institutionalism in Comparative Analysis. Cambridge: Cambridge University Press.

Stern, Paul C., Thomas Dietz, Nives Dolsak, Elinor Ostrom, and Susan Stonich

2002 Knowledge and Questions After 15 Years of Research. In The Drama of the Commons. Thomas Dietz, Elinor Ostrom, Nives Dolsak, Paul C. Stern, Susan Stonich, and Elke U. Weber, eds. Pp. 445-491. Washington, D.C.: National Academy Press.

Torres-Maldonado, Eduardo Jose

1997 From Tropical Hell to Tourist Paradise: State Intervention and Tourist Entrepreneurship in the Mexican Caribbean. Austin: University of Texas.

2000 El Caribe Mexicano Hacia el Siglo XXI (del como y el porque Quintana Roo, un ifierno tropical y expresidio politico, devino en un paraiso Turistico moderno y en una compleja sociedad mexicana-caribena y Fronteriza). In Diacronica Del Caribe
Mexicano: Una Historia de Quintana Roo y Cancun. Eduardo Jose Torres-Maldonado, ed. Pp. 145-255. Mexico, D.F.: Universidad Autonoma Metropolitana.

Vasquez-Leon, Marcela

1994 Avoidance Strategies and Governmental Rigidity: The Case of The Small-Scale Shrimp Fishery in Two Mexican Communities. Journal of Political Ecology 1:67-81.

Weber, Max

1978 Economy and Society: An Outline of Interpretive Sociology. Guenther Roth and Claus Wittich, trans. Berkeley: University of California Press.

Wells, Michael, and Katrina Brandon

1992 People and Parks: Linking Protected Area Management with Local Communities. Washington D.C.: The World Bank, United States Agency for International Development and World Wildlife Fund.

Wells, Michael, and Thomas McShane

2004 Integrating Protected Area Management with Local Needs and Aspirations. Ambio 33(8):513-518.

Wells, Susan, and Alan T. White

1995 Involving the Community. In Marine Protected Areas: Principles and Techniques for Management. Susan Gubbay, ed. Pp. 61-84. London: Chapman and Hall.

West, Patrick C.

1991 Introduction. In Resident Peoples and National Parks: Social Dilemmas and Strategies in International Conservation. Patrick C. West and Steven R. Brechin, eds. Pp. Xv-xxiv. Tucson: University of Arizona Press.

West, Patrick C., and Steven R. Brechin, eds.

1991 Resident Peoples and National Parks: Social Dilemmas and Strategies in International Conservation. Tucson: University of Arizona Press.

Western, David, and R. Michael Wright

1994a The Background to Community Based Conservation. In Natural Connections: Perspectives in Community-Based Conservation. David Western and R. Michael Wright, eds. Pp. 1-14. Washington, D.C.: Island Press.

1994b Natural Connections: Perspectives in Community-Based Conservation. Washington, D.C.: Island Press

Wilshusen, Peter R., Steven R. Brechin, Crystal L. Fortwangler, and Patrick C. West

2002 Reinventing a Square Wheel: Critique of a Resurgent "Protection Paradigm" in International Biodiversity Conservation. Society and Natural Resources 15:17-40.

2003 Contested Nature: Conservation and Development at the Turn of the Twenty- First Century. In Contested Nature: Promoting International Biodiversity with Social Justice in the TwentyFirst Century. Peter R. Wilshusen, Steven R. Brechin, Crystal L. Fortwangler, and Patrick C. West, eds. Pp. 1-22. Albany: State University of New York Press.

Young, Emily

2001 State Intervention and Abuse of the Commons: Fisheries Development in Baja California Sur, Mexico. Annals of the Association of American Geographers 91(2): 283-306. 